\title{
Melatonin suppresses cisplatin-induced nephrotoxicity via activation of Nrf-2/HO-1 pathway
}

Ulkan Kilic ${ }^{*}$, Ertugrul Kilic², Zeynep Tuzcu ${ }^{3}$, Mehmet Tuzcu ${ }^{3}$, Ibrahim H Ozercan ${ }^{4}$, Okkes Yilmaz ${ }^{3}$, Fikrettin Sahin ${ }^{5}$ and Kazim Sahin ${ }^{6}$

\begin{abstract}
Background: Cisplatin, one of the most effective and potent anticancer drugs, is used in the treatment of a wide variety of both pediatric and adult malignancies. However, the chemotherapeutic use of cisplatin is limited by its serious side-effects such as nephrotoxicity and ototoxicity. Cisplatin chemotherapy induces a reduction in the antioxidant status, leading to a failure of the antioxidant defense against free-radical damage generated by antitumor drugs. Cisplatin-induced oxidative stress in the kidney was partially prevented by antioxidant treatments using superoxide dismutase, glutathione, selenium and flavonoids. Melatonin and its metabolites possess free-radical scavenging activity and it has been shown that they protect against cisplatin toxicity. However, the mechanism of the protective effects of melatonin against cisplatin-induced nephrotoxicity is still essentially unknown. We therefore designed this study to investigate the underlying mechanism of the protective effect of melatonin against cisplatin-induced renal damage in a rat nephrotoxicity model in vivo.
\end{abstract}

Methods: Twenty eight 8-week-old male Wistar rats were divided into four groups of control, melatonin treatment ( $4 \mathrm{mg} / \mathrm{kg}$ b.w i.p. for 10 days), cisplatin treatment (7 mg/kg b.w., i.p.) and melatonin and cisplatin combination treatment. Serum urea nitrogen (urea-N) and creatinine levels were measured. Histopathological changes were evaluated. In addition, we analyzed the expression levels of HO-1, Nrf2, NF-kB and AP-1 in Western blot analysis.

Results: Both serum creatinine and urea nitrogen increased significantly following cisplatin administration alone; these values decreased significantly with melatonin co-treatment of cisplatin-treated rats. Histological analysis showed that cisplatin caused damage in the proximal tubular cells in the kidneys of cisplatin-treated rats; these changes were reversed by melatonin co-treatment. Upon Western blot analysis, melatonin treatment increased Nrf2 accumulation in the nuclear fraction, and increased the expression of HO-1 in the cytosolic fraction as compared to the cisplatin-treated rats. Expressions of NF-KB p65 and AP-1 were increased significantly in the kidneys of rats treated with cisplatin compared with the expression in the kidneys from the control, melatonin-only-treated and melatonin co-treated rats.

Conclusion: Our present data suggest that melatonin attenuates cisplatin-induced nephrotoxicity possibly by modulating $\mathrm{Nrf} 2 / \mathrm{HO}-1$ signaling.

Keywords: Nephrotoxicity, Nrf2/HO-1 signaling, Melatonin, Oxidative stress

\footnotetext{
* Correspondence: uckilic@yahoo.com

'Department of Medical Biology, Faculty of Medicine, Bezmialem Vakif University, Adnan Menderes Bulvarı Vatan Caddesi, Fatih, TR-34093, Istanbul, Turkey

Full list of author information is available at the end of the article
}

\section{Biomed Central}

(c) 2013 Kilic et al.; licensee BioMed Central Ltd. This is an Open Access article distributed under the terms of the Creative Commons Attribution License (http://creativecommons.org/licenses/by/2.0), which permits unrestricted use, distribution, and reproduction in any medium, provided the original work is properly cited. 


\section{Background}

Cisplatin (cis-diamminedichloroplatinum) is a widely used antineoplastic drug for the treatment of various cancer types $[1,2]$. However, its use is limited by its nephrotoxicity with about $25-35 \%$ of patients experiencing a significant decline in renal function after a single dose of cisplatin treatment [3]. Recent studies showed that cisplatin induce DNA adduct formation, leading to aberrant genetic transcription and DNA duplication, cell cycle arrest, and induction of apoptosis [4]. Further, increased generation of reactive oxygen species (ROS), which are often involved in renal dysfunction, has been reported in cisplatin-induced nephrotoxicity [5-8]. The mechanism of cisplatin-induced nephrotoxicity is not completely understood; however, several mechanisms, including hypoxia, free radicals, inflammation, and apoptosis are thought to be involved. Excessive production of free radicals, such as superoxide anion, hydrogen peroxide, and hydroxyl radicals, and the occurrence of lipid peroxidation due to oxidative stress are associated with cisplatin-induced renal dysfunction $[9,10]$.

In many cell types, numerous cellular responses to oxidative stress have been found to be involved in signaling proteins that act through the antioxidant response element (ARE) and the transcription factor, the nuclear factor erythroid 2-related factor 2 (Nrf2) [11]. Nrf2, is a redox-sensitive transcription factor, which mainly regulates transcriptional activation through the ARE $[12,13]$. Under physiological conditions, cytosolic Nrf2 is inactive by its negative regulator Kelch-like ECH-associating protein 1 (Keap1). When cells are exposed to redox modulators, Nrf2 is released from Keap1, translocates and accumulates in the nucleus. Nrf2 forms a heterodimer with a small Maf protein and c-jun [14]. It has been recently documented that as Nrf2 activators various compounds such as polyphenols (curcumin and resveratrol), sulfur-containing compounds (isothiocyanate sulforaphane, phenethyl isothiocyanate), terpenoids (cafestol and kahweol), carotenoids ( $\beta$-carotene), and selenium induce the expression of cytoprotective protein in an ARE-dependent manner [15].

Redox sensitive molecular targets including transcription factors nuclear factor- $\mathrm{kB}(\mathrm{NF}-\mathrm{kB})$ and activator protein 1 (AP-1) contain highly conserved cysteine residues and their oxidation, and nitration are essential in the oxidant/redox signaling. Both NF-kB and AP-1 are activated by various physiological and pathological stimuli including ROS directly or their generation through mitochondria [16] and orchestrate expression of many genes playing roles in inflammation, embryonic development, lymphoid differentiation, oncogenesis, and apoptosis [17].

Melatonin (N-acetyl-5-methoxytriptamine) is synthesized and released into the circulation and especially into cerebrospinal fluid by the pineal gland in a circadian rhythm [18] and is also produced by immune system cells, brain, airway epithelium, bone marrow, gut, ovary, testes, skin and likely other tissues [19]. Melatonin and its metabolites possess free-radical scavenging activity $[20,21]$. Melatonin has both receptor-mediated and receptor independent actions and is believed to affect all cells $[22,23]$. Melatonin increases mRNA and protein levels of antioxidant enzymes through Nrf2 activation [24,25]. Negi et al. (2011) reported that melatonin ameliorates neuroinflammation and oxidative stress through Nrf2 and NF- $\mathrm{kB}$ in experimental diabetic neuropathy. Upregulation of $\mathrm{Nrf} 2$ by melatonin resulted in an increased expression of antioxidant enzyme heme oxygenase-1 (HO-1) [26].

Cisplatin-induced oxidative stress in kidneys was partially prevented by antioxidant treatments using superoxide dismutase, glutathione, selenium and flavonoids [27]. Melatonin has been shown to protect against cisplatin toxicity $[28,29]$. However, the mechanism of the protective effects of melatonin against cisplatin-induced nephrotoxicity is still essentially unknown. We therefore designed this study to investigate the mechanism of the protective effect of melatonin against in vivo cisplatininduced renal damage in a rat nephrotoxicity model.

For this purpose, serum urea nitrogen (urea-N) and creatinine levels were measured. Histological changes were evaluated and the expression levels of $\mathrm{HO}-1, \mathrm{Nrf} 2$, $\mathrm{NF}-\mathrm{kB}$ and AP-1 were analyzed in Western blot analysis.

\section{Experimental methods \\ Animals}

Male Wistar rats ( $\mathrm{n}=28,8$ wk-old), weighing 200-215 g, were obtained from Firat University Research Center (Elazig, Turkey). The rats were kept in an environmentally controlled room at constant temperature $\left(21 \pm 1^{\circ} \mathrm{C}\right)$ and humidity $(75 \pm 5 \%)$ under a $12 \mathrm{~h}$ light/dark cycle. The animals were acclimatized for 1 week before the study and had free access to standard laboratory feed and water ad libitum. The study has the permission of Ethics Review Committee for Ethics in Animal Experiments of the Firat University and guidelines for the Care and Use of Laboratory animals were strictly followed.

\section{Experimental protocol}

Kidney injury was induced by a single intraperitoneal (i.p.) injection of cisplatin (Sigma Chemical Co, USA) $(7 \mathrm{mg} / \mathrm{kg}$ b.w.) [30]. Twenty-eight 8-week-old male Wistar rats were divided into four groups of control treated with vehicle, melatonin-treated ( $4 \mathrm{mg} / \mathrm{kg}$ b.w, i.p. at 17:00 hr. for 10 days) [31], (Sigma-Aldrich, St Louis, MO, USA), cisplatin treated (7 mg/kg b.w., i.p.), and melatonin $(4 \mathrm{mg} / \mathrm{kg}$ b.w., i.p. at 17:00 hr. for 10 days) and cisplatin $(7 \mathrm{mg} / \mathrm{kg}$ b. w., i.p.) co-treated.

Melatonin administration was started two days before the single i.p. injection of cisplatin. Melatonin was dissolved in ethanol and diluted in saline. Final ethanol 
Table 1 The effect of melatonin administration on urea- $N$ and creatinine levels in kidney of experimental rats ( $n=10)$

\begin{tabular}{llllr}
\hline Item & Groups & & & \\
\cline { 2 - 5 } & Control & Melatonin & Cisplatine & Melatonin + Cisplatine \\
\hline Urea- $\mathrm{N}(\mathrm{mg} / \mathrm{dl})$ & $31.5 \pm 3.4^{c}$ & $30.9 \pm 2.0^{c}$ & $438.9 \pm 63.1^{\mathrm{a}}$ & $209.0 \pm 42.5^{\mathrm{b}}$ \\
Creatinine $(\mathrm{mg} / \mathrm{dl})$ & $0.68 \pm 0.19^{c}$ & $0.67 \pm 0.14^{c}$ & $3.61 \pm 0.43^{\mathrm{a}}$ & $1.91 \pm 0.57^{\mathrm{b}}$ \\
\hline
\end{tabular}

Values are mean \pm SE of 10 rats from each group. a, b, c: means in the same row not sharing a common superscript are significantly different $(P<0.05)$ between groups.

concentration was $1 \%$. On day 12 (10 days after the cisplatin treatment), all rats were sacrificed by cervical dislocation under anesthesia (1\% Halothane). Blood samples were taken for serum analyses and the kidneys were removed for histological studies and Western blot analysis.

\section{Biochemical measurement}

Blood samples were centrifuged at $3.000 \mathrm{~g}$ for $10 \mathrm{~min}$, and sera were collected. Serum urea nitrogen (urea-N) and creatinine were measured using biochemical analyzer (Olympus AU-660, Osaka, Japan).

\section{Western blot analysis}

Protein extraction was performed by homogenizing the rat kidneys in $1 \mathrm{ml}$ ice-cold hypotonic buffer $\mathrm{A}$, containing $10 \mathrm{mM}$ HEPES (pH 7.8), $10 \mathrm{mM} \mathrm{KCl}, 2 \mathrm{mM} \mathrm{MgCl}, 1 \mathrm{mM}$ DTT, $0.1 \mathrm{mM}$ EDTA, and $0.1 \mathrm{mM}$ phenylmethylsulfonylfluoride (PMSF). To the homogenates $80 \mu \mathrm{l}$ of $10 \%$ Nonidet P-40 (NP-40) solution was added, and the mixture was centrifuged for $2 \mathrm{~min}$ at $14,000 \mathrm{~g}$. Supernatant containing the cytosolic fraction was collected for $\mathrm{HO}-1$. The precipitate containing the nuclear fraction was separated for Nrf2, NFkB-65 and AP-1, washed with $500 \mu \mathrm{l}$ of buffer A plus $40 \mu \mathrm{l}$ of $10 \%$ NP-40, centrifuged, resuspended in $200 \mu \mathrm{l}$ of buffer C [50 mM HEPES (pH 7.8), $50 \mathrm{mM} \mathrm{KCl,} 300 \mathrm{mM} \mathrm{NaCl}$, $0.1 \mathrm{mM}$ EDTA, $1 \mathrm{mM}$ DTT, $0.1 \mathrm{mM}$ PMSF, 20\% glycerol], and centrifuged for $5 \mathrm{~min}$ at $14,800 \mathrm{~g}$. The supernatant from the abovementioned precipitate was collected for Nrf2, NF-kB p65 and AP-1. Protein concentrations were determined according to the procedure described by Lowry using a protein assay kit supplied by Sigma (St. Louis, MO, USA). Sodium dodecyl sulfate-polyacrylamide gel electrophoresis sample buffer containing $2 \%$ b-mercaptoethanol was added to the supernatant. Equal amounts of protein $(50 \mu \mathrm{g})$ were electrophoresed and subsequently transferred to a nitrocellulose membrane (Schleicher and Schuell Inc., Keene, NH, USA). Blots on the nitrocellulose membrane were washed twice for 5 min each in PBS and blocked with $1 \%$ bovine serum albumin in PBS for $1 \mathrm{~h}$ prior to the application of the primary antibody. Antibodies against Nrf2, HO-1, NF-кB p65 and AP-1 were purchased from Abcam (Cambridge, UK). Primary antibody was diluted (1:1000) in the same buffer containing $0.05 \%$ Tween-20. The nitrocellulose membrane was incubated overnight at $4^{\circ} \mathrm{C}$ with primary antibody. The blots were washed and incubated with horseradish peroxidase-conjugated goat anti-mouse IgG
(Abcam, Cambridge, UK). Specific binding was detected using diaminobenzidine and $\mathrm{H}_{2} \mathrm{O}_{2}$ as substrates. Protein loading was controlled using a monoclonal mouse antibody against ß-actin (A5316; Sigma). Bands were analyzed densitometrically using an image analysis system (Image J; National Institute of Health, Bethesda, USA).

\section{Histological analysis}

The left kidney from each animal was immediately fixed in $20 \%$ neutral buffered formalin solution for histopathology. Kidneys were gradually dehydrated, embedded in paraffin, cut into 5- $\mu \mathrm{m}$ sections, and stained with hematoxylin and eosin for histological examination according to standard procedure [32]. Histological changes were evaluated semiquantitatively by a pathologist unaware of the type of treatment. A minimum of 10 fields for each kidney slide was examined and assigned for severity of changes using the following scale: - , none; + , mild damage; ++ , moderate damage; and +++ , severe damage.

\section{Statistical analysis}

Sample size was calculated based on a power of $85 \%$ and a p-value of 0.05. Given that assumption, a sample size of 7 per treatment was calculated. The data were analyzed using the GLM procedure of SAS (2002). The treatments were compared using ANOVA and $\mathrm{p}<0.05$ was considered statistically significant. Inter-group differences in latencies were determined by the analysis of variance for repeated measurements (ANOVAR) followed by Fisher's post hoc test for all groups.

\section{Results}

\section{Biochemical measurement}

Both serum creatinine and urea nitrogen increased significantly following cisplatin administration alone; these values decreased significantly with melatonin co-treatment of cisplatin-treated rats (Table 1).

\section{Western blot analysis}

Expressions of NF- $\mathrm{BB}$ p65 and AP-1 were increased significantly in the kidneys of rats treated with cisplatin compared with the expression in the kidneys from the control, melatonin-only-treated and melatonin co-treated rats $(P<0.05)$ (Figure 1$)$. In Figure 1 it was shown that melatonin treatment increased Nrf2 accumulation in the nuclear fraction $(P<0.05)$, and increased the expression 
Figure 1 Western blot analysis of NF-kB p65, AP-1, Nrf2 (nuclear fraction) and $\mathrm{HO}-1$ (cytosolic fraction) in kidney cells in rats: Western blot using the anti- NF-KB (Panel A), AP-1 (Panel B), Nrf2 (Panel C) and hemeoxygenese-1 (HO-1; Panel D) revealed specific bands. Blots were repeated at least 3 times. $\beta$-actin levels were monitored to ensure equal protein loading (bottom panel). The intensity of the bands was quantified by the densitometric analysis. Data are percent of the control. a-c: Means in the same line without a common superscript differ significantly $(P<0.05)$.

of $\mathrm{HO}-1$ in the cytosolic fraction as compared to the cisplatin-treated rats $(P<0.05)$.

A

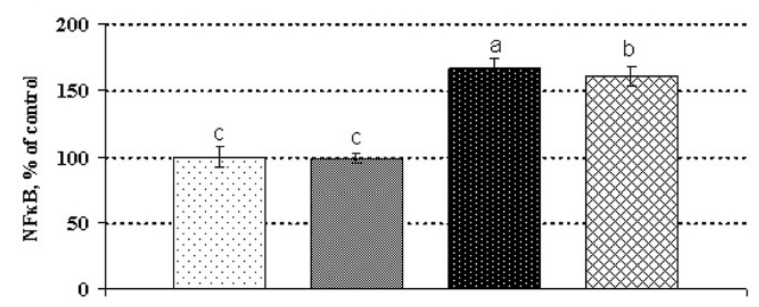

B

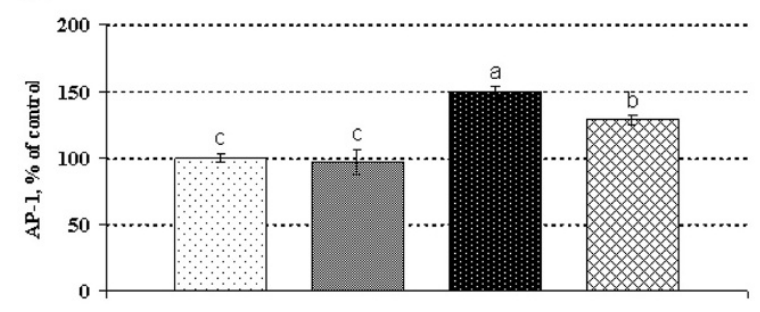

C

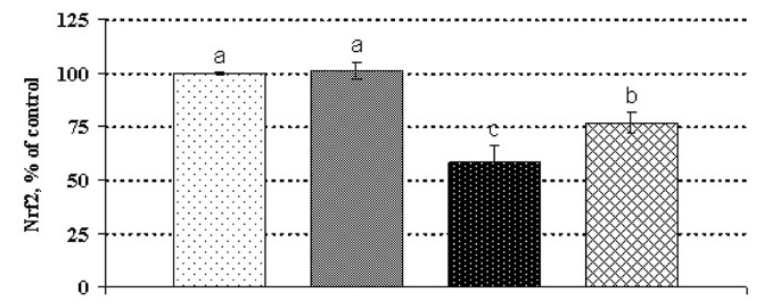

D

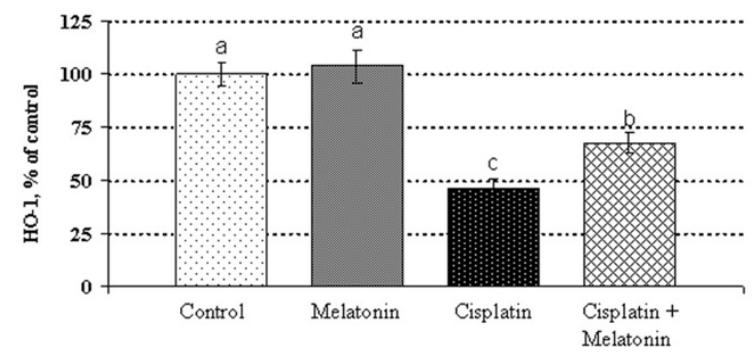

\section{Histological analysis}

The kidneys from the control rats and the rats treated with melatonin only showed no abnormality, whereas the kidneys from the cisplatin-treated rats showed marked histological changes in the cortex and outer medulla, such as vacuolation (v), interstitial edema (ie), tubular atrophy (ta), severe tubular necrosis (tn), and interstitial inflammation (ii). Melatonin treatment decreased the cisplatininduced tubular necrosis and most of the changes were caused by cisplatin treatment (Figure 2, Table 2).

\section{Discussion}

The present study demonstrates that the administration of melatonin exerts a renal protective effect in a rat model of nephrotoxicity provoked by a single injection of cisplatin. We analyzed expressions of $\mathrm{HO}-1, \mathrm{Nrf} 2, \mathrm{NF}-\kappa \mathrm{B}$ and AP-1 in Western blot analysis. The expressions of Nrf2 and HO-1 were increased significantly. Expressions of NF-kB p65 and AP-1 were increased significantly in the kidneys of rats treated with cisplatin compared with the expression in the kidneys from the control, melatonin-only-treated and melatonin co-treated rats.

Both serum creatinine and urea nitrogen increased significantly in cisplatin treated animals; however, these effects of cisplatin reversed by melatonin treatment. Histological analysis showed that cisplatin damaged the proximal tubular cells; these changes were prevented by melatonin co-treatment. Melatonin alone did not show any significant effect on NF-kB, AP-1, Nrf2 and HO-1 in the kidneys of animals without cisplatin treatment. In previous studies, it has been shown that cisplatin enhances the production of ROS, decreases the antioxidant enzyme levels, enhances the level of TNF- $\alpha$ [33], and induces apoptosis [34] while triggering its toxicity. ROS generated by cisplatin are crucial for Nrf2-driven transcriptional activation of ARE. This led us to expect that cisplatin might induce nuclear translocation of Nrf2, and activate NF-kB; NF-kB activation by ROS has been reported in a previous study [35]. Nrf2 is a basic leucine zipper transcription factor, which transcriptionally regulates many genes including $\mathrm{HO}-1$, 


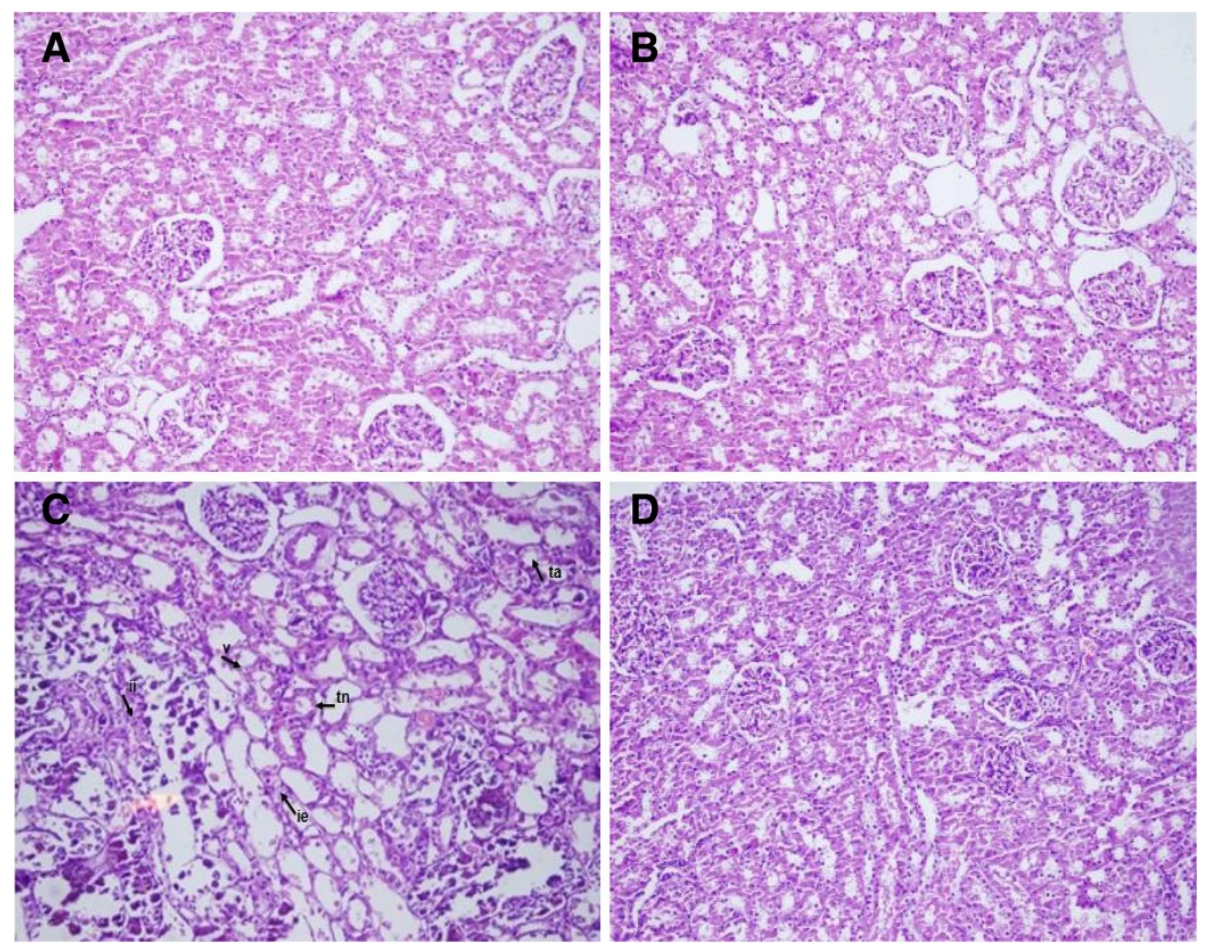

Figure 2 Histological changes in renal tissues in response to cisplatin and cisplatin+melatonin: The day when animals injected cisplatin is Day $\mathbf{0}$ and the histological changes in the renal tissues on day $\mathbf{1 0}$ are indicated. A, Control; B, melatonin treatment alone; C, cisplatin treatment alone [left to right (ii) interstitial inflammation, (v) vaculation, (ie) interstitial edema, (tn) tubular necrosis, (ta) tubular atrophy]; D, cisplatin+melatonin. Magnification: $\times 200$.

NAD(P) H:quinine oxidoreductase-1, c-glutamylcysteine synthase, and glutathione S-transferase [36]. The inactive form of Nrf2 is localized in the cytoplasm bound to a cytoskeleton-associated protein, Keap1. Its activation is considered to be an important molecular target of many chemopreventive and cytoprotective agents [37-39]. Nrf2 protects the cell against oxidative stress through AREmediated induction of several phase 2 detoxifying and antioxidant enzymes, particularly the HO- $138-40]$. HO- 1 is a stress-responsive enzyme, responsible for the breakdown of heme to biliverdin, free iron and carbon monoxide [36,41]. It is induced by a variety of cellular stresses, including heme, hyperoxia, hypoxia, and electrophiles $[36,39]$. Beni et al., (2004) reported that the activation of transcription factor Nrf2 influenced by the cell redox, which acts as a sensor of electrophiles and prooxidant stressors [42]. Oxidative stress and inflammation are two of the most critical factors implicated in cisplatin-induced nephrotoxicity. While Nrf2 upregulates the expression of a number of antioxidant proteins, role of ROS in inflammation via the activation of NF-kB has been investigated in cisplatin-induced renal injury [43]. Recent studies have shown the interaction between nuclear Nrf2 and NF-kB signaling $[24,36]$. The studies also report that Nrf2-

Table 2 The effect of melatonin administration on morphological changes as assessed by histological analysis of kidneys in rats $(n=10)$

\begin{tabular}{lllll}
\hline & Groups & & \\
\cline { 2 - 5 } Changes & Control & Melatonin & Cisplatine & Melatonin + Cisplatine \\
\hline Vaculation & - & - & ++ & + \\
Interstitial edema & - & - & + & $+/-$ \\
Tubular brush border loss & - & - & + & + \\
Tubular necrosis & - & - & + & $+/-$ \\
Tubular atrophy & - & - & +++ & $+/-$
\end{tabular}

- , none; + , mild damage; ++ , moderate damage; and +++ , severe damage are semiquantitative scores given by a pathologist unaware of the type of treatment according to method of Ross et al. (1989). 
deficient mice display increased NF- $\mathrm{B}$ activation in response to lipopolysaccharides [44]. Furthermore, disruption of Nrf2 enhances the upregulation of NF- $\mathrm{BB}$ and proinflammatory cytokines in the brain after traumatic brain injury $[36,45]$. Cisplatin treatment showed an inverse correlation between the two transcriptions factors, which is in agreement with previous studies.

Melatonin (N-acetyl 5-methoxytryptamine) and its metabolites have been shown to enforce the antioxidant system by scavenging free radicals [21,46]. Melatonin stimulates synthesis of antioxidant enzymes [47] and increases the activities of other antioxidants [48,49]. Furthermore, melatonin protects antioxidative enzymes from oxidative damage [50]. Wang et al., (2009) previously showed that melatonin was effective in preventing cardiopulmonary bypass-induced renal damage probably through its antioxidant function and upregulation of HO-1 [51]. The indole, melatonin, is well tolerated, has a low interaction potential with other medications and in some cases may even reduce the side effects of synthetic drugs because of its free-radical scavenging properties [52]. We and others have previously shown that melatonin, which based on its small molecular size and high lipophilicity, possesses excellent biological membrane permeability and minimal side effects in humans $[18,23,53]$, reduces brain injury in mouse [23,54-56] and rat $[57,58]$ models of ischemic stroke.

Melatonin as an antioxidant has been investigated in various animal models such as age related neurodegeneration [59], in traumatic brain injury [44], left ventricular hypertrophy [60] and antibiotic-induced nephrotoxicity such as anthracyclin antibiotics, and gentamicin [61,62] and in different nephrotoxic models $[63,64]$. In the last decade, in various models of acute and chronic tissue injury and oxidative stress, it has been shown that the main mechanism for melatonin's protective effect is its action through indirect (transcriptional) effects. It has been recently shown that the melatonin-derived protection of heart damage caused by acute exercise in rats is associated with the NF- $\mathrm{B}$ dependent control of inflammatory and pro-oxidant pathways $[65,66]$. In a model of acute renal damage in rats, melatonin was found to improve markers of oxidative stress by increased expression of the antioxidant and detoxification enzyme HO-1 [50] or by inhibition of the inducible form of NOS and also of p38 MAPK and NF- $\mathrm{kB}$ activation [67].

Beni et al. (2004) reported that AP-1 transcription factor inhibition by melatonin played an important role in the late protection response to traumatic brain injury [42]. Hepatoprotective effects of melatonin were demonstrated in rats after acute intoxication with dimethylnitrosamine, which provides further support to a role for melatonin as a secondary antioxidant and detoxification agent [66]. The mechanism seems to be related to negative modulation of $\mathrm{NF}-\mathrm{kB}$-dependent genes activated in response to stress.

\section{Conclusion}

In conclusion, the present study was carried out to investigate the expressions of $\mathrm{Nrf} 2, \mathrm{HO}-1 \mathrm{NF} \kappa \mathrm{B}$ and $\mathrm{AP} 1$ after a single cisplatin injection in rats. We evaluated the possible prevention of cisplatin-induced oxidative stress in the kidney with melatonin administration. Here, we report that melatonin attenuates cisplatin-induced nephrotoxicity in rats by modulating Nrf2/HO- 1 signaling. Expressions of NF-kB p65 and AP-1 were increased significantly in the kidneys of rats treated with cisplatin compared with the expression in the kidneys from the control, melatonin-only-treated and melatonin cotreated rats. Nrf2/HO-1 signaling pathway upregulates the expression of a number of antioxidant genes in response to a wide array of stimuli, and protects the cell against oxidative stress and inflammation [39]. The results of this study indicate a possible association between $\mathrm{Nrf} 2 / \mathrm{HO}-1$ antioxidative stress signaling and melatonin's nephroprotective effect.

These data may have research hints at therapeutic uses for melatonin. Melatonin may be beneficial in the prevention of cisplatin-induced nephrotoxicity. However, additional clinical studies are needed to evaluate the role of preventive melatonin treatment in humans. The mechanisms of melatonin's effect in terms of $\mathrm{Nrf} 2 / \mathrm{HO}-1$ regulation including some other transcription factors could be further investigated.

\section{Competing interests}

The authors declare that there are no competing interests.

\section{Authors' contribution}

The project was designed and implemented by UK and KS. Data were analyzed by EK, ZT, MT, IHO, OY and FS. UK prepared the manuscript. UK and KS supervised overall project. All authors read and approved the final version of manuscript.

\section{Acknowledgements}

This work was supported by EMBO (European Molecular Biology Organization) installation grant and The Turkish Academy of Sciences (TUBA).

\section{Author details}

${ }^{1}$ Department of Medical Biology, Faculty of Medicine, Bezmialem Vakif University, Adnan Menderes Bulvarı Vatan Caddesi, Fatih, TR-34093, Istanbul, Turkey. ${ }^{2}$ Department of Physiology, Faculty of Medicine, Medipol University, Istanbul, Turkey. ${ }^{3}$ Department of Biology, Faculty of Science, Firat University, Elazig, Turkey. ${ }^{4}$ Department of Pathology, Faculty of Medicine, Firat University, Elazig, Turkey. ${ }^{5}$ Department of Genetics and Bioengineering, Yeditepe University, Istanbul, Turkey. ${ }^{6}$ Department of Animal Nutrition, Faculty of Veterinary Science, Firat University, Elazig, Turkey.

Received: 7 August 2012 Accepted: 8 January 2013

Published: 12 January 2013

\section{References}

1. Safirstein R, Winston J, Goldstein M, Moel D, Dikman S, Guttenplan J: Cisplatin nephrotoxicity. Am J Kidney Dis 1986, 8:356-367.

2. Osanto S, Bukman A, Van Hoek F, Sterk PJ, De Laat JA, Hermans J: Longterm effects of chemotherapy in patients with testicular cancer. J Clin Oncol 1992, 10:574-579.

3. Luke DR, Vadiei K, Lopez-Berestein G: Role of vascular congestion in cisplatin-induced acute renal failure in the rat. Nephrol Dial Transplant 1992, 37(1):1-7. 
4. Jamieson ER, Lippard SJ: Structure, recognition, and processing of cisplatin-DNA adducts. Chem Rev 1999, 99:2467-2498.

5. Davis CA, Nick HS, Agarwal A: Manganese superoxide dismutase attenuates cisplatin-induced renal injury: importance of superoxide. J Am Soc Nephrol 2001, 12:2683-2690.

6. Rahman I, Biswas SK, Kirkham PA: Regulation of inflammation and redox signaling by dietary polyphenols. Biochem Pharmacol 2006, 72:1439-1452.

7. Shimeda Y, Hirotani Y, Akimoto Y, Shindou K, ljiri Y, Nishihori T, Tanaka K: Protective effects of capsaicin against cisplatin-induced nephrotoxicity in rats. Biol Pharm Bull 2005, 28:1635-1638.

8. Santos NA, Catão CS, Martins NM, Curti C, Bianchi ML, Santos AC: Cisplatininduced nephrotoxicity is associated with oxidative stress, redox state unbalance, impairment of energetic metabolism and apoptosis in rat kidney mitochondria. Arch Toxicol 2007, 81:495-504.

9. Kotins MS, Patel P, Menon SN, Sane RT: Renoprotective effect of Hemidesmus indicus, a herbal drug used in gentamicin-induced renal toxicity. Nephrology 2004, 9:142-147.

10. Rao NK, Nammi S: Antidiabetic and renoprotective effects of the chloroform extract of Terminalia chebula Retz. seeds in treptozotocininduced diabetic rats. BMC Complement Altern Med 2006, 6:17-22.

11. Sies $H$, Masumoto $H$ : Ebselen as a glutathione peroxidase mimic and as a scavenger of peroxynitrite. Adv Pharmacol 1997, 38:229-246.

12. Huang HC, Nguyen T, Pickett CB: Phosphorylation of Nrf2 at Ser-40 by protein kinase $C$ regulates antioxidant response element-mediated transcription. J Biol Chem 2002, 277:42769-42774.

13. Lee JM, Li J, Johnson DA, Stein TD, Kraft AD, Calkins MJ, Jakel RJ, Johnson JA: Nrf2, a multi-organ protector? FASEB J 2005, 19:1061-1066.

14. Motohashi H, O'Connor T, Katsuoka F, Engel JD, Yamamoto M: Integration and diversity of the regulatory network composed of Maf and CNC families of transcription factors. Gene 2002, 294:1-12.

15. Yates MS, Kensler TW: Keap1 eye on the target: chemoprevention of liver cancer. Acta Pharmacol Sin 2007, 28:1331-1342.

16. Baldwin AS Jr: The NF-kappa B and I kappa B proteins: new discoveries and insights. Annu Rev Immunol 1996, 14:649-683.

17. Li Q, Verma IM: NF-kappaB regulation in the immune system. Nat Rev Immunol 2002, 2:725-734. 48

18. Reiter RJ, Tan DX, Leon J, Kilic U, Kilic E: When melatonin gets on your nerves: its beneficial actions in experimental models of stroke. Exp Biol Med (Maywood) 2005, 230:104-117.

19. Reiter RJ, Paredes SD, Manchester LC, Tan DX: Reducing oxidative/ nitrosative stress: a newly-discovered genre for melatonin. Crit Rev Biochem Mol Biol 2009, 44:175-200.

20. Hardeland R, Tan DX, Reiter RJ: Kynuramines, metabolites of melatonin and other indoles: the resurrection of an almost forgotten class of biogenic amines. J Pineal Res 2009, 47:109-126.

21. Tan DX, Manchester LC, Terron MP, Flores LJ, Reiter RJ: One molecule, many derivatives: a never-ending interaction of melatonin with reactive oxygen and nitrogen species? J Pineal Res 2007, 42:28-42.

22. Reiter RJ, Tan DX, Manchester LC, Pilar Terron M, Flores LJ, Koppisetti S: Medical implications of melatonin: receptor-mediated and receptorindependent actions. Adv Med Sci 2007, 52:11-28.

23. Kilic U, Yilmaz B, Ugur M, Yuksel A, Reiter RJ, Hermann DM, Kilic E: Evidence that membrane-bound $\mathrm{G}$ protein-coupled melatonin receptors MT1 and MT2 are not involved in the neuroprotective effects of melatonin in focal cerebral ischemia. J Pineal Res 2012, 52:228-235.

24. Jung KH, Hong SW, Zheng HM, Lee DH, Hong SS: Melatonin downregulates nuclear erythroid 2-related factor 2 and nuclear factorkappaB during prevention of oxidative liver injury in a dimethylnitrosamine model. J Pineal Res 2009, 47:173-183.

25. Jung KH, Hong SW, Zheng HM, Lee HS, Lee H, Lee DH, Lee SY, Hong SS: Melatonin ameliorates cerulein-induced pancreatitis by the modulation of nuclear erythroid 2-related factor 2 and nuclear factor-kappaB in rats. J Pineal Res 2010, 48:239-250.

26. Negi G, Kumar A, Sharma SS: Melatonin modulates neuroinflammation and oxidative stress in experimental diabetic neuropathy: effects on NF-KB and Nrf2 cascades. J Pineal Res 2011, 50:124-131.

27. Anand $\mathrm{AH}$, Bashey B: Newer insights into cisplatin nephrotoxicity. Ann Pharmacother 1993, 27:1519-1525.

28. Morishima I, Okumura K, Matsui H, Kaneko S, Numaguchi Y, Kawakami K, Makuno S, Hayakawa M, Toki Y, Ito T, Hayakawa T: Zinc accumulation in
Adriamycin-induced cardiyomyopathy in rats: Effects of melatonin, a cardiyoprotective agent. J Pineal Res 2004, 26:204-210.

29. Lopez-Gonzales MA, Guerrero JM, Toronteras R, Osuna C, Delgado F: Ototoxicity caused by aminoglucusides is ameliorated by melatonin without interfering with the antibiotic capacity of the drugs. $J$ Pineal Res 2000, 28:26-33.

30. Sahin K, Tuzcu M, Sahin N, Ali S, Kucuk O: Nrf2/HO-1 signaling pathway may be the prime target for chemoprevention of cisplatin-induced nephrotoxicity by lycopene. Food Chem Toxicol 2010, 48:2670-2674.

31. Kilic U, Kilic E, Reiter RJ, Bassetti CL, Hermann DM: Signal transduction pathways involved in melatonin-induced neuroprotection after focal cerebral ischemia in mice. J Pineal Res 2005, 38:67-71.

32. Ross MH, Reith EJ, Romrell L: Histology-A Text and Atlas (ki sp k). Baltimore, MD: Williams and Wilkins; 1989

33. Ramesh G, Reeves WB: TNF-alpha mediates chemokine and cytokine expression and renal injury in cisplatin nephrotoxicity. J Clin Invest 2002, 110(6):835-842.

34. Tsuruya K, Ninomiya T, Tokumoto M, Hirakawa M, Masutani K, Taniguchi M, Fukuda K, Kanai H, Kishihara K, Hirakata H, lida M: Direct involvement of the receptor-mediated apoptotic pathways in cisplatin induced renal tubular cell death. Kidney Int 2003, 63:72-82.

35. Ali S, Mann DA: Signal transduction via the NF-kappaB pathway: a targeted treatment modality for infection, inflammation and repair. Cell Biochem Funct 2004, 22:67-79.

36. Surh YJ, Na HK: NF-kappaB and Nrf2 as prime molecular targets for chemoprevention and cytoprotection with anti-inflammatory and antioxidant phytochemicals. Genes Nutr 2008, 2:313-317.

37. Prawan A, Kukongviriyapan V, Tassaneeyakul W, Pairojkul C, Bhudhisawasdi $\mathrm{V}$ : Association between genetic polymorphisms of CYP1A2, arylamine Nacetyltransferase 1 and 2 and susceptibility to cholangiocarcinoma. Eur J Cancer Prev 2005, 14:245-250.

38. Prawan A, Kundu JK, Surh YJ: Molecular basis of heme oxygenase-1 induction: implications for chemoprevention and chemoprotection. Antioxid Redox Signal 2005, 7:1688-1703.

39. Surh YJ, Kundu JK, Na HK: Nrf2 as a master redox switch in turning on the cellular signaling involved in the induction of cytoprotective genes by some chemopreventive phytochemicals. Planta Med 2008, 74:1526-1539.

40. McNally A, Dalton T, La Ragione RM, Stapleton K, Manning G, Newell DG: Yersinia enterocolitica isolates of differing biotypes from humans and animals are adherent, invasive and persist in macrophages, but differ in cytokine secretion profiles in vitro. J Med Microbiol 2006, 55:1725-1734

41. Maines MD, Gibbs PE: 30 some years of heme oxygenase: from a "molecular wrecking ball" to a "mesmerizing" trigger of cellular events. Biochem Biophys Res Commun 2005, 338:568-577.

42. Beni SM, Kohen R, Reiter RJ, Tan DX, Shohami E: Melatonin-induced neuroprotection after closed head injury is associated with increased brain antioxidants and attenuated late-phase activation of NF-kappaB and AP-1. FASEB J 2004, 18(1):149-151.

43. Lee S, Moon SO, Kim W, Sung MJ, Kim DH, Kang KP, Jang YB, Lee JE, Jang KY, Lee SY, Park SK: Protective role of L-2-oxothiazolidine-4-carboxylic acid in cisplatin-induced renal injury. Nephrol Dial Transplant 2006, 21:2085-2095

44. Thimmulappa RK, Lee H, Rangasamy T, Reddy SP, Yamamoto M, Kensler TW, Biswal S: Nrf2 is a critical regulator of the innate immune response and survival during experimental sepsis. J Clin Invest 2006, 116:984-995.

45. Jin W, Wang H, Yan W, Xu L, Wang X, Zhao X, Yang X, Chen G, Ji Y: Disruption of Nrf2 enhances upregulation of nuclear factor-kappaB activity, proinflammatory cytokines, and intercellular adhesion molecule1 in the brain after traumatic brain injury. Mediators Inflamm 2008, 72:51-74

46. Hardeland R, Backhaus C, Fadavi A: Reactions of the NO redox forms NO+, ${ }^{*} \mathrm{NO}$ and $\mathrm{HNO}$ (protonated NO) with the melatonin metabolite N1-acetyl-5-methoxykynuramine. J Pineal Res 2007, 43:382-388.

47. Reiter RJ, Tan DX, Osuna C, Gitto E: Actions of melatonin in the reduction of oxidative stress. A review. J Biomed Sci 2000, 7:444-458.

48. Urata Y, Honma S, Goto S, Todoroki S, lida T, Cho S, Honma K, Kondo T: Melatonin induces gammaglutamylcysteine synthetase mediated by activator protein-1 in human vascular endothelial cells. Free Radic Biol Med 1999, 27:838-847.

49. Gitto E, Tan DX, Reiter RJ, Karbownik M, Manchester LC, Cuzzocrea S, Fulia F, Barberi I: Individual and synergistic antioxidative actions of melatonin: 
studies with vitamin $E$, vitamin C, glutathione and desferrioxamine (desferoxamine) in rat liver homogenates. J Pharm Pharmacol 2001, 53:1393-1401

50. Mayo JC, Tan DX, Sainz RM, Lopez-Burillo S, Reiter RJ: Oxidative damage to catalase induced by peroxyl radicals: functional protection by melatonin and other antioxidants. Free Radic Res 2003, 37:543-553. 2009.

51. Wang Z, Zhang J, Liu H, Huang H, Wang C, Shen Y, Li D, Jing H: Melatonin, a potent regulator of hemeoxygenase-1, reduces cardiopulmonary bypass-induced renal damage in rats. J Pineal Res 2009, 46:248-254.

52. Reiter RJ, Tan DX, Sainz RM, Mayo JC, Lopez-Burillo S: Melatonin: reducing the toxicity and increasing the efficacy of drugs. J Pharm Pharmacol 2002, 54:1299-1321.

53. Cheung RT, Tipoe GL, Tam S, Ma ES, Zou LY, Chan PS: Preclinical evaluation ofpharmacokinetics and safety of melatonin in propylene glycol for intravenous administration. J Pineal Res 2006, 41:337-343.

54. Kilic E, Kilic U, Reiter RJ, Bassetti CL, Hermann DM: Prophylactic use of melatonin protects against focal cerebral ischemia in mice: role of endothelin converting enzyme-1.J Pineal Res 2004, 37:247-251.

55. Kilic E, Kilic U, Yulug B, Hermann DM, Reiter RJ: Melatonin reduces disseminate neuronal death after mild focal ischemia in mice via inhibition of caspase-3 and is suitable as an add-on treatment to tissueplasminogen activator. J Pineal Res 2004, 36:171-176. 16.

56. Kilic E, Kilic U, Reiter RJ, Bassetti CL, Hermann DM: Tissue-plasminogen activator- induced ischemic brain injury is reversed by melatonin: role of iNOS and Akt. J Pineal Res 2005, 39:151-155.

57. Pei Z, Pang SF, Cheung RT: Pretreatment with melatonin reduces volume of cerebral infarction in a rat middle cerebral artery occlusion stroke model. J Pineal Res 2002, 32:168-172.

58. Sun FY, Lin X, Mao LZ, Ge WH, Zhang LM, Huang YL, Gu J: Neuroprotection by melatonin against ischemic neuronal injury associated with modulation of DNA damage and repair in the rat following a transient cerebral ischemia. J Pineal Res 2002, 33:48-56.

59. Ortiz GG, Benitez-King GA, Rosales-Corral SA, Pacheco-Moises FP, VelazquezBrizuela IE: Cellular and biochemical actions of melatonin which protect against free radicals: role in neurodegenerative disorders. Curr Neuropharmacol 2008, 6:203-214.

60. Paulis L, Pechanova O, Zicha J, Krajcirovicova K, Barta A, Pelouch V, Adamcova M, Simko F: Melatonin prevents fibrosis but not hypertrophy development in the left ventricle of NG-nitro-l-arginine-methyl ester hypertensive rats. J Hypertens 2009, 27(Suppl. 6):S11-S16.

61. Sener G, Sehirli AO, Altunbas $H$, Ersoy Y: Melatonin protects against gentamicin-induced nephrotoxicity in rats. J Pineal Res 2002, 32:231-236.

62. Dziegiel P, Suder E, Surowiak P, Jethon Z, Rabczyński J, Januszewska L, Sope $\mathrm{M}$, Zabel M: Role of exogenous melatonin in reducing the nephrotoxic effect of daunorubicin and doxorubicin in the rat. J Pineal Res 2002, 33:95-100.

63. Nava M, Romero F, Quiroz Parra G, Bonet L, Rodriguez-Iturbe B: Melatonin attenuates acute renal failure and oxidative stress induced by mercury chloride in rats. Am J Physiol Renal Physiol 2000, 279:F910-F918.

64. Hara M, Yoshida M, Nishijima H, Yokosuka M, ligo M, Ohtani-Kaneko R, Shimada A, Hasegawa T, Akama Y, Hirata K: Melatonin, a pineal secretory product with antioxidant properties, protects against cisplatin-induced nephrotoxicity in rats. J Pineal Res 2001, 30:129-138.

65. Luchetti F, Canonico B, Betti M, Arcangeletti M, Pilolli F, Piroddi M, Canesi L, Papa S, Galli: Melatonin signaling and cell protection function. FASEB 2010, 24(10):3603-3624.

66. Veneroso C, Tunon MJ, Gonzalez-Gallego J, Collado PS: Melatonin reduces cardiac inflammatory injury induced by acute exercise. J Pineal Res 2009, 47:184-191.

67. Ozbek E, llbey YO, Ozbek M, Simsek A, Cekmen M, Somay A: Melatonin attenuates unilateral ureteral obstruction- induced renal injury by reducing oxidative stress, iNOS, MAPK, and NF-KB expression. J Endourol 2009, 23:1165-1173.

doi:10.1186/1743-7075-10-7

Cite this article as: Kilic et al: Melatonin suppresses cisplatin-induced nephrotoxicity via activation of Nrf-2/HO-1 pathway. Nutrition \& Metabolism 2013 10:7.

\section{Submit your next manuscript to BioMed Central and take full advantage of:}

- Convenient online submission

- Thorough peer review

- No space constraints or color figure charges

- Immediate publication on acceptance

- Inclusion in PubMed, CAS, Scopus and Google Scholar

- Research which is freely available for redistribution 